\title{
S-nitroso-human-albumin
}

\section{A new therapeutic approach in endotoxic shock}

\author{
Andrzej Jakubowski \\ Institute of Experimental Pharmacology, Jagiellonian University School of Medicine, Kraków, Poland
}

\section{KEY WORDS}

nitric oxide, septic shock, S-nitroso-human-serum-albumin

\section{ABSTRACT}

INTRODUCTION Endotoxemia leads to induction of inducible nitric oxide synthase (iNOS) and increased expression of numerous inflammatory mediators, contributing to endotoxin-induced acute lung injury.

OBJECTIVES We examined the hypothesis that supplementation of nitric oxide (NO) with the novel NO donor, S-nitroso-human-serum-albumin (S-NO-HSA), may reduce iNOS expression, lung inflammation and acute lung injury in a rat model of septic shock.

MATERIAL AND METHOdS Rats were divided into 4 groups: sham-operated (no treatment), LPS (lipopolysaccharide), LPS + HSA, and LPS + S-NO-HSA. Endotoxin-induced (20 $\mathrm{mg} \mathrm{kg}^{-1}$, iv) lung injury was characterized by measurement of wet/dry weight ratio (pulmonary edema), myeloperoxidase activity (pulmonary neutrophil infiltration), expression of intercellular adhesion molecule-1, iNOS, and cyclooxygenase-2.

RESULTS LPS-induced acute lung injury involved pulmonary edema, neutrophil infiltration and a strong inflammatory response, resulting in high mortality within $6 \mathrm{~h}$. S-NO-HSA prolonged survival of endotoxemic rats, reduced hypotensive response to LPS, and minimized LPS-induced lung edema by modulation of systemic inflammatory response.

CONCLUSIONS NO supplementation with S-NO-HSA after LPS administration prevents induction of iNOS protects against endotoxin-induced acute lung injury, and reduces early mortality in endotoxic rats. The results of the study support a therapeutic role of S-NO-HSA in the treatment of endotoxemia.

INTRODUCTION Normal levels of nitric oxide (NO) in the body are essential to maintain homeostasis in the cells, tissues and organs. In vivo administration of lipopolysaccharide (LPS) causes systemic inflammatory response with subsequent respiratory distress syndrome and septic shock. ${ }^{1}$ Endotoxic shock has two distinct phases. The first one occurs almost immediately after LPS injection and involves transient pulmonary hypertension and systemic hypotension with concomitant cardiac dysfunction and a decrease in cardiac output. ${ }^{2}$ A number of studies have indicated that these acute effects are caused by the sudden release of lipid mediators (platelet-activating factor, thromboxanes, leukotrienes, and others) and cytokines (tumor necrosis factor- $\alpha$, interleukin [IL]-2, IL-6, IL-8), which markedly affect the respiratory and cardiovascular systems. The delayed phase, which occurs a few hours after LPS injection, involves a gradual decrease in blood pressure with accompanying vasoplegia, tis sue hypoperfusion, microvascular damage, and multiple organ injury. It is generally accepted that the majority of these alterations are mediated by NO, produced by inducible nitric oxide synthase (iNOS), which is up-regulated by endotoxin. On the other hand, NO generated by constitutive endothelial nitric oxide synthase (eNOS) seems to play a cytoprotective role, especially in the early phase of endotoxemia. A substantial body of evidence shows that inhibition of iNOS in septic shock or endotoxemia reverses hypotension and restores vascular responsiveness to vasoconstrictor agents. ${ }^{3,4}$ However, in a number of these studies nonselective inhibitors, e.g. $\mathrm{N}^{G}$-nitro-L-arginine methyl ester (L-NAME) or $\mathrm{L}-\mathrm{N}^{\mathrm{G}}$-monomethyl arginine (L-NMMA), were used to inhibit iNOS, which at the same time 
reduced the protective effect of NO produced by eNOS in the endothelium. Excessive vasoconstriction, caused by L-NAME treatment, leads to abnormal perfusion ${ }^{5}$, depression of the cardiovascular system ${ }^{6}$, enhanced liver ${ }^{7}$, intestine ${ }^{8}$ and lung ${ }^{9,10}$ injury, thus increasing mortality rate in septic shock ${ }^{11}$.

Despite several studies, the protective effect of NO produced by eNOS in host response to LPS is still unclear. It may result from vasodilator $^{5}$, antiplatelet ${ }^{12}$ or antileukocyte ${ }^{13}$ activities of endothelial NO. Additionally, constitutively produced or supplemented NO can actively prevent endothelial dysfunction by maintaining local L-arginine concentration around the enzyme, which is sufficient to minimize NOS derangement and reactive oxygen species production. Interestingly, increased resistance to LPS-induced mortality in transgenic mice with overexpression of eNOS, was shown to result from cytoprotective activity of NO in the lungs. ${ }^{14}$ These data are supported by the finding that NO supplementation with S-nitroso- $\mathrm{N}$-acetylpenicillamine in the early phase of endotoxemia effectively protected against LPS-induced lung injury. ${ }^{10}$ There have been attempts to use exogenous NO to reduce endotoxin-induced lung injury. However, clinically used NO donors show high variability with regard to the NO synthesis pathway ${ }^{15}$, and, most importantly, significantly decrease blood pressure, which limits their use in septic shock. Tolerance, especially to organic nitrates, also restrict their therapeutic use. ${ }^{15,16}$ Therefore, a new approach using novel, stable S-nitroso-human-serum-albumin (S-NO-HSA) in the treatment of septic shock in an endotoxemic rat model has been proposed. ${ }^{17}$

S-NO-HSA undergoes degradation following application to NO and albumin, and hence serves as a carrier of NO to the endothelium. ${ }^{18}$ It is a high molecular weight S-nitrosothiol, which has an exact equimolar S-nitrosation, and a high S-nitrosograde (S-NO- in position Cys-34 of HSA: $\sim 0.8 \mathrm{~mol} \mathrm{~mol}^{-1}$ protein) due to defined pre-processing. Compared to the low molecular weight S-nitrosothiols, S-NO-HSA has a prolonged half-life of approximately $15 \mathrm{~min}$. It has been shown that NO supplemented by S-NO-HSA, at concentrations causing no hypotension, reduces ishemia/reperfusion injury of the skeletal and cardiac muscle tissue by preserving endothelial functions in the microcirculation. ${ }^{19,20}$ S-NO-HSA also inhibited platelet aggregation and leukocyte-endothelial cell adhesion. ${ }^{21}$

Material and methods Anesthetized and intubated male Wistar rats were instrumentated and endotoxic shock was induced by intravenous infusion of LPS $\left(20 \mathrm{mg} \mathrm{kg}^{-1}\right)$. Rats were divided into 4 groups: sham operated, LPS, LPS + human serum albumin (HSA) and LPS + S-NO-HSA.

Infusion of S-NO-HSA or HSA was started $2 \mathrm{~h}$ after LPS and continued for $4 \mathrm{~h}$ (total dose: $72 \mathrm{mg} \mathrm{kg}^{-1}$ ). In all experimental groups hemo- dynamic parameters were monitored. Six hours after LPS administration animals were sacrificed and the following parameters were analyzed:

1 lung injury assessed by microscopyy (hematoxylin-eosin staining)

2 lung edema assessed by a ratio of wet/dry (W/D) weight

3 pulmonary neutrophil infiltration assessed based on the myeloperoxidase (MPO) activity (spectrophotometric assay)

4 lung inflammatory response assessed by intercellular adhesion molecule-1 (ICAM-1) protein expression, iNOS protein and mRNA expression (Western Blot). Additionally, the level of cyclooxygenase-2 (COX-2) mRNA was measured (reverse transcription polymerase chain reaction).

In another set of experiments, survival rates were studied. Rats were randomly divided into four groups as described above. Data were expressed as mean \pm SEM. Statistical differences between means were determined by ANOVA followed by a post hoc comparison. Survival data were analyzed using the Kaplan-Maier test. A p $<0.05$ was considered statistically significant.

RESULTS Infusion of S-NO-HSA and HSA did not cause significant changes in mean arterial pressure (MAP). All rats from the LPS and LPS + HSA groups died $6 \mathrm{~h}$ after LPS challenge. Treatment with S-NO-HSA prevented LPS-induced mortality. No death was noted in the LPS + S-NO-HSA group $6 \mathrm{~h}$ after LPS challenge. After LPS injection a progressive and severe decrease in MAP occurred. S-NO-HSA-treated rats were more resistant to LPS-induced hypotension compared to the LPS and LPS + HSA groups. In sham-operated animals MAP remained constant throughout the experiment.

Histological examination of the lung was performed in specimens obtained $6 \mathrm{~h}$ after LPS infusion. In contrast to the sham operated animals, LPS and LPS + HSA caused interalveolar membrane thickening (interstitial edema), alveolar damage and leukocyte infiltration. These effects of LPS were substantially reduced by S-NO-HSA treatment.

There was approximately a threefold increase in W/D lung weight ratio $6 \mathrm{~h}$ after LPS injection. In the LPS + S-NO-HSA group W/D ratio was significantly lower and in the LPS + HPS group slightly lower compared to LPS group.

Six hours after LPS injection MPO activity, reflecting pulmonary granulocyte infiltration, increased dramatically. MPO response in the LPS + HSA and LPS groups was similar. An increase in MPO activity was significantly attenuated in the LPS + S-NO-HSA group.

While in sham operated animals iNOS and ICAM-1 were barely detectable, LPS markedly increased expression of both proteins. Treatment with S-NO-HSA prevented LPS-induced induction of pulmonary iNOS and ICAM-1. HSA alone did not lower and even slightly increased 
LPS-induced expression of iNOS and ICAM-1. LPS also caused a significant increase in mRNA expression of iNOS and COX-2 compared to sham operated animals. HSA treatment did not alter the effect of LPS. Again, similarly to anti-inflammatory effects on protein level and in contrast to HSA alone, S-NO-HSA significantly decreased the expression of mRNA iNOS and COX-2.

DISCUSSION The study demonstrated that S-NO-HSA administered after LPS challenge prevented early mortality, reduced hemodynamic disturbances and acute lung injury in endotoxic rats. S-NO-HSA prevented excessive damage of pulmonary tissue by modulation of pulmonary inflammatory response. Accordingly, use of a novel NO donor enabled to combat endothelial NO deficiency in endotoxic shock. Despite iNOS induction and markedly increased total NO production in endotoxic shock, there exists a relative, local deficiency of eNOS-derived NO at the level of microcirculation. ${ }^{22}$ This may be particularly important for the integrity of pulmonary microcirculation. Our results are in line with these observations, and therefore we propose a novel approach to treat lung injury associated with endotoxemia by using adequate NO supplementation with S-NO-HSA.

The results of this and other experimental studies on the use of S-NO-HSA in the prevention of ischemic damage on cellular level demonstrate the need for further investigation and clinical trials.

\section{REFERENCES}

1 Jaeschke RZ, Brożek JL, Dellinger RP. 2008 update of international guidelines for the management of severe sepsis and septic shock: should we change our current clinical practice? Pol Arch Med Wewn. 2008; 118 : 92-95.

2 Oh-Ishi S, Ishida H, Ueno A. Role of synergistic action of PAF and kinin in bacterial endotoxin-induced hypotention in rats. Adv Exp Med Biol. 1996; 416: 235-238.

3 Thiemermann C. Nitric oxide and septic shock. Gen Pharmacol. 1997; 29: 159-166.

4 Kirkebøen KA, Strand OA. The role of nitric oxide in sepsis - an overview. Acta Anaesthesiol Scand. 1999; 43: 275-288.

5 Spain DA, Wilson MA, Garrison RN. Nitric oxide synthase inhibition exacerbates sepsis-induced renal hypoperfusion. Surgery. 1994; 116 322-330.

6 Offner PJ, Robertson FM, Pruitt BA Jr. Effects of nitric oxide synthase inhibition on regional blood flow in a porcine model of endotoxic shock. J Trauma. 1995; 39: 338-343.

7 Harbrecht BG, Billiar TR, Stadler J, et al. Nitric oxide synthesis serves to reduce hepatic damage during acute murine endotoxemia. Crit Care Med. 1992; 20: 1568-1574.

8 Laszlo F, Whittle BJ, Moncada S. Time-dependent enhancement or inhibition of endotoxin-induced vascular injury in rat intestine by nitric oxide synthase inhibitors. Br J Pharmacol. 1994; 111: 1309-1315.

9 Park JH, Chang $\mathrm{SH}$, Lee KM, et al. Protective effect of nitric oxide in an endotoxin-induced septic shock. Am J Surg. 1996; 171: 340-345.

10 Gryglewski RJ, Wolkow PP, Uracz W, et al. Protective role of pulmonary nitric oxide in the acute phase of endotoxemia in rats. Circ Res. 1998; 82: 819-827.

11 Cobb JP. Use of nitric oxide synthase inhibitors to treat septic shock: the light has changed from yellow to red. Crit Care Med. 1999; 27: 855-856.

12 Shultz PJ, Raij L. Endogenously synthesized nitric oxide prevents endotoxin-induced glomerular thrombosis. J Clin Invest. 1992; 90: 1718-1725.

13 Laszlo F, Whittle BJ, Moncada S. Attenuation by nitrosothiol NO donors of acute intestinal microvascular dysfunction in the rat. $\mathrm{Br} \mathrm{J}$ Pharmacol. 1995; 115: 498-502.
14 Yamashita T, Kawashima S, Ohashi Y, et al. Resistance to endotoxin shock in transgenic mice overexpressing endothelial nitric oxide synthase. Circulation. 2000; 101: 931-937.

15 Feelisch M. The biochemical pathways of nitric oxide formation from notrosovasodilators: appropriate choice of exogenous NO donors and aspects of preparation and handling of aqueous solutions. J Cardiovasc Pharmacol. 1991; 17: S25-S33.

16 16. Bauer JA, Fung HL. Differential hemodynamic effects and tolerance properties of nitroglycerin and an S-nitrosothiol in experimental heart failure. J Pharmacol Exp Ther. 1991; 256: 249-254.

17 Jakubowski A, Maksimovich N, Olszanecki R, et al. S-nitroso human serum albumin given after LPS challenge reduces acute lung injury and prolongs survival in a rat model of endotoxemia. Naunyn Schmiedebergs Arch Pharmacol. 2009; 379: 281-290.

18 Hallström S, Gasser H, Neumayer Ch, et al. S-Nitroso human serum albumin treatment in ischemia/reperfusion injury of skeletal muscle - biochemical aspects. Shock. 1999; Suppl. 12: 4.1

19 Hallström S, Gasser H, et al. S-Nitroso human serum albumin treatment reduces ischemia/reperfusion injury in skeletal muscle via nitric oxide release. Circulation. 2002; 105: 3032-3038.

20 Semsroth S, Fellner B, Trescher K, et al: S-nitroso human serum albumin attenuates ischemia/reperfusion injury after cardioplegic arrest in isolated rabbit hearts. J Heart Lung Transplant. 2005; 24: 2226-2234.

21 C Bauer, W Kuntz, F Ohnsmann, et al. The attenuation of hepatic microcirculatory alterations by exogenous substitution of nitric oxide by s-nitroso-human albumin after hemorrhagic shock in the rat. Shock. 2004; 21: $165-169$

22 Munzel T, Daiber A, Ullrich V, et al. Vascular consequences of endothelial nitric oxide synthase uncoupling for the activity and expression of the soluble guanylyl cyclase and the cGMP-dependent protein kinase. Arterioscler Thromb Vasc Biol. 2005; 25: 1551-1557. 


\title{
S-nitrozo-albumina ludzka
}

\section{Nowe podejście terapeutyczne do leczenia wstrząsu endotoksycznego}

\author{
Andrzej Jakubowski \\ Zakład Farmakologii Doświadczalnej, Uniwersytet Jagielloński, Collegium Medicum, Kraków
}

\section{SŁOWA KLUCZOWE}

S-nitrozo-albumina ludzka, tlenek azotu, wstrząs septyczny
Adres do korespondencji: dr med. Andrzej Jakubowski, Zakład Farmakologii Doświadczalnej, Uniwersytet Jagielloński, Collegium Medicum, ul. Grzegórzecka 16, 31-531 Kraków,

tel.: 0-12-421-11-68, fax: 0-12-421-72-17, e-mail: mfjakubo@cyf-kr.edu.pl Praca wpłynęta: 30.04 .2009 . Przyjęta do druku: 13.05 .2009 Nie zgloszono sprzeczności interesów.

Pol Arch Med Wewn. 2009; 119 (7-8): 501-504

Copyright by Medycyna Praktyczna, Kraków 2009

\section{STRESZCZENIE}

WPROWADZENIE Endotoksemia powoduje indukcję indukowalnej syntazy tlenku azotu (inducible nitric oxide synthase - iNOS) oraz zwiększa ekspresję licznych mediatorów zapalnych, prowadząc do ostrego uszkodzenia płuc.

CELE Sprawdzana była hipoteza, że uzupełnianie puli tlenku azotu (nitric oxide - NO) przy pomocy nowego donora NO, S-nitrozo-albuminy ludzkiej (S-nitroso-human-serum-albumin - S-NO-HSA), może zredukować ekspresję iNOS, zmiany zapalne i uszkodzenie tkanki płucnej w szczurzym modelu wstrząsu septycznego.

MATERIAL I METODY Szczury zostały podzielone na 4 grupy: kontrolną (bez leczenia), LPS (lipopolisacharyd), LPS + HSA i LPS + S-NO-HSA. Uszkodzenie płuc wywołane endotoksyną $\left(20 \mathrm{mg} \mathrm{kg}^{-1}\right.$, iv) scharakteryzowano poprzez oznaczenie stosunku mokrej do suchej masy tkanki płucnej (obrzęk płuc), aktywności mieloperoksydazy (neutrofilowe nacieki zapalne), ekspresji międzykomórkowej cząsteczki adhezyjnej typu 1, iNOS i cyklooksygenazy-2.

WYNIKI Spowodowane przez LPS ostre uszkodzenie płuc obejmowało obrzęk płuc, nacieki neutrofilowe wraz z silną odpowiedzią zapalną skutkującą dużą śmiertelnością zwierząt w ciągu 6 h. S-NO-HSA wydłużyła czas przeżycia szczurów, zmniejszyła spowodowaną przez LPS odpowiedź hipotensyjną oraz obrzęk płuc poprzez modulację ogólnoustrojowej reakcji zapalnej.

WNIOSKI Uzupetnianie NO za pomocą S-NO-HSA po podaniu LPS-u hamuje indukcję iNOS, prowadzi do znaczącej ochrony przed ostrym uszkodzeniem płuc oraz zmniejsza wczesną śmiertelność we wstrząsie septycznym u szczurów. Wyniki badania potwierdzają skuteczność terapeutyczną S-NO-HSA w leczeniu endotoksemii. 